\title{
The Relationship between Budgetary Institutions and Efficiencies: Changes after the Implementation of the Top-Down Budgeting System*
}

\begin{abstract}
Yunho Gang**
Abstract: This paper provides an empirical analysis of the relationship between the top-down budgeting system and allocative efficiencies (budgetary outcomes) in the case of the Korean central government. From the perspective of New Institutionalism, a comparative analysis between the bottom-up budgeting system and the top-down budgeting system was carried out. The results of the analysis confirm the relationships between budgeting institutions, action situations, budgeting participants' interactions, and allocative efficiencies. The changes in budgeting rules, and thus in action situations, due to the implementation of the top-down budgeting system led to changes in budgeting participants' behaviors and thus in budgetary outcomes. Two behavior patterns-excessive budget requests by departments and huge budget cuts by the central budget office-were both greatly reduced. The resulting budgetary outcomes (allocative efficiencies) were changed. These changes were assessed to be reasonably beneficial in the context of the Korean budgeting situation.
\end{abstract}

Keywords: Top-down Budgeting System, Budgetary Institution, Allocative Efficiency

\section{INTRODUCTION}

President Roh's government in Korea introduced substantial financial innovations including the top-down budgeting system (TDB), performance budgeting, and other

* This work was supported by the Korea Research Foundation Grant funded by the Korean Government (MOEHRD) (KRF-2006-332-B00550).

** Yunho Gang is an associate professor, Department of Public Maritime Administration, Korea Maritime University. He received his Ph.D. in Public Administration from the Graduate School of Public Administration at Seoul National University in 1999. His research interests fall into two categories of public budgeting and institutional analysis.

Manuscript received August 2008; out for review November 2008; review completed November 2008; accepted November 2008.

The Korean Journal of Policy Studies, Vol. 23, No. 2, 79-108 (2009)

(C) 2009 by the GSPA, Seoul National University 
changes. In most countries that have implemented TDB, its main purpose was to constrain governmental expenditures and decrease financial deficits. The main purpose of the TDB in Korea, however, has been to improve allocative efficiencies. Before TDB was introduced in Korea, allocative inefficiencies were very problematic for three reasons: (1) excessive budget requests by departments and agencies (budget-maximizing behavior), (2) huge budget cuts by the central budget office, and (3) centralized and short-sighted annual budgeting under the bottom-up budgeting system (BUB) previously employed by the Korean central budget office (Byeon 2002; Presidential Committee on Government Innovation and Decentralization 2005, 127-33; Ryu 2004; Lee 2006).

In Korea, the BUB was plagued with allocative inefficiencies. These outcomes were associated with Korean incrementalism, as well as the budget-maximizing behavior that has long been predicted by public choice theorists. That is, on the one hand, fragmented and short-sighted annual budgets had been made based on the previous fiscal year's budget and focused on budgeting by individual programs. Budget proposals from each department were then significantly cut or reorganized by the central budget office. ${ }^{1}$ On the other hand, bureaucrats' opportunistic behaviors had so increased that they continually sought to maximize their respective organizational budgets. The purpose of introducing TDB was to overcome the inefficiencies resulting from these budgeting behaviors.

The purpose of this paper is to provide an empirical analysis of the effects of TDB in the case of the Korean central government. Did the introduction of TDB lead to a change in allocative efficiencies (budgetary outcomes)? If so, was the change beneficial? This paper intends to answer these questions.

The analyses of budgetary outcome or efficiency have been carried out largely from the perspectives of incrementalism and public choice. According to incrementalism, budgetary decision-makers increase their organizational budgets piecemeal, without deep assessment of the validity of budgetary programs, using the previous fiscal year's budget as a base. Public choice assumes that bureaucratic self-interested behavior in budgeting will give rise to allocative inefficiency of resources. Niskanen's (1971) budget-maximizer model is one of the most frequently quoted papers written from the perspective of public choice. According to this model, the bureaucrat who has self-interested motivation seeks to maximize his bureau's budget, and thus brings about the excessive expansion of public finance. There are also some analyses which address the relationship between budgetary rules and budgetary outcomes from the

1. From this point of view, Korean incrementalism in budgeting was a very centralized type of decision-making, contrary to the typical incrementalism defined by Wildavsky (1988), et al. 
perspective of institutionalism (for example, Ostrom 1986, 3-25).

A public budget has the attributes of the commons for bureaucrats within the department of the executive branch. This is because each department has both the right of budget request and of potential budget use (non-excludability), and the more one department receives its share the less there is for others (subtractability). In these situations, the tragedy of the commons (prisoner's dilemma), which is inefficiency in budget use in this case, is likely to occur. Therefore, it seems that institutional theories which address the problems of commons can be useful in analyzing budgeting. It is the essence of TDB that after the budget office sets a spending ceiling for every executive department and sector, each department autonomously allocates its budget within the ceiling. Setting a ceiling is analogous to setting quasi-property rights to budget, or the rights of budget-use, for every department and sector (Bae 2004, 147-57). Will this lead to changes in the efficiencies of resources allocation? This paper intends to provide the answer through the theory of New Institutionalism, especially the Institutional Analysis and Development Framework (IAD) developed by Ostrom (2005), which analyzes the problem of the commons.

\section{LITERATURE REVIEW}

In TDB, the central budget office first sets the total government expenditure and the spending ceiling for each department and sector, in order to strategically allocate budget. Then, within that ceiling, each department allocates its budget to individual programs (Ehrhart, Gardner, von Hargen, and Keser 2005). This system is an innovation that seeks to change budgeting participants' behaviors and budgetary outcomes by changing budgetary institutions.

Four theoretical perspectives have been used to analyze budget allocation: normative perspective theory, political system theory, organizational process perspective theory, and public choice theory (Kraan 1996). Of these four, incrementalism (organizational process perspective) and public choice are closely connected with the study of the relationship between budgetary institutions, budgeting participants' interactions, and budgetary outcome.

Budgeting theory from the perspective of public choice provides a useful framework for understanding bureaucrats' behaviors in the budgeting process, as well as the types of interactions between the departments, the central budget office, and the legislative body (Forrester 2001, 101-24). Most public choice theories insist that bureaucrats' self-interested motivations will lead to the excessive expansion of public budgets or a degree of governmental output that goes beyond the optimal level. Von Hargen and 
Harden (1996) proved through the Nash Equilibrium that inefficient allocation of resources results from the difference between two contradictory objectives of expenditure which the central budget office and the spending department seek to maximize, respectively. That is, each department recognizes the costs of its expenditures only in terms of its own position and thus perceives these costs as smaller than its real costs. Thus, each department requests a budget larger than its actual needs. However, the central budget office sees the costs from a national perspective and so tries to constrain the expenditure to the socially optimal level. A spending department tries to control its information in order to maximize its budget and to prevent a decrease in funding, even with regard to programs that are deemed useless. Therefore, through the process of negotiation and coordination between the central budget office and the spending department, more public resources are allocated than the socially optimal level.

Niskanen supposed that bureaucrats seek to maximize their bureau budgets in order to improve their own individual benefits, and succeed in budget-maximizing because of the asymmetry of information between bureaucrats and their sponsors. The resulting outcome is excessive expansion of the public budget. According to Niskanen (1971), rational bureaucrats' self-interested motivation leads to allocative inefficiency.

There have been many critiques of Niskanen's model. First, some have argued that, although it is generally recognized that bureaucrats are rational utility-maximizers, they may not seek to maximize their bureau budgets, because their objective functions differ significantly from what Niskanen supposed, namely individual material benefit. Migue and Belanger $(1974,24-43)$ argued that because bureaucrats are mostly interested in managerial discretion, they seek to maximize their bureau's discretionary budgets instead of unconditionally trying to increase their bureau outputs. According to Margolis's analysis (1975, 645-59), career-oriented bureaucrats may be more dedicated to doing good jobs than to expanding their bureau budgets for career advancement, and thus may seek to minimize their bureau budgets. Wilson (1989) found that bureaucrats may employ certain strategies, such as staff decrease or budget minimization, in order to achieve independence (autonomy) for their bureau. Other analysts concluded that bureaucrats have other objectives such as on-the-job leisure (Peacock 1983), avoidance of responsibility (Tullock 1965) or risk (Auster 1975), job stability (Peters 1978, 175), or political freedom and autonomy (Moe 1990, 116-53).

Second, others argued that, in addition to their own utility maximization, some bureaucrats may have other types of motivations, such as public service motivation including public interests, loyalty, and other motivations (Margolis 1975; Musgrave 1981, 77-120; Rainey 1983, 207-42; Kelman 1988; Perry \& Wise 1990, 370). Indeed, some bureaucrats may seek to provide efficient and effective services rather than service expansion (Rubin 2006, 13). 
According to incrementalists, due to bounded rationality and the complexity of situations, budgeting participants consider only marginal changes based on current expenditure as a budget base to decrease the burden of calculus (Davis, Demster, \& Wildavsky 1966; Wildavsky \& Caiden, 2004, 43-50). In the decision-making process, bureaucrats are depicted as satisficers rather than maximizers - they do not seek to get all they want, but rather all they can. If an agency maximizes its budget request, then the budget bureau and appropriation committees that review and appropriate expenditures will not trust the agency and will automatically cut down the budget significantly without any detailed review. Therefore, the agency will not be able to justify even its prior programs. That is, to request a moderate increase is ultimately more advantageous in getting budget approval than to request an excessive increase. Therefore, bureaucrats will set more moderate goals and use more moderate strategies in order to keep the trust of the evaluating office (Wildavsky 1988, 86-87). According to incrementalist logic, thus, bureaucrats will consider small changes from current budget levels due to: (1) bounded rationality and (2) the strategy of getting a budget approved. As a result, the change in budgetary outcomes will be small.

Some analyses have shown that bureaucrats' budgeting behaviors are affected by diverse factors. For example, political sponsors (the legislative body) have an effect on bureaucratic budgeting (Markris 2006, 275-92; Leloup 1984, 78-98). Bureaucratic policy preferences may be constrained by the chief executive (Calvert, McCubbins, \& Weingast 1989, 588-611; Bendor \& Moe 1985). Agency budget requests are reviewed and coordinated by governors or their central budget offices in pursuit of the governors' policy initiatives (Abney \& Lauth 1989, 829-40). An agency budget request is dependent on the values, attitudes, and orientation of the agency administrator. Assertive, mission-oriented agency heads will pursue budget expansion for their programs, while more conservative administrators might act nonassertively (Leloup and Moreland 1978, 232-39). Interest group or clientele group activities could be positively correlated with agency agenda and budget requests (LeLoup 1984, 81). Ryu, Bowling, Cho, and Wright (2007, 22-49) empirically tested the effects of administrators' aspirations, political principals' priorities, and interest groups' influence on agency budget requests. Sigelman (1986, 50-59) said that bureaucrats' commitment to budget requests is related to their devotion to their jobs, as well as their affirmative views of government roles and the characteristics of those jobs assigned to them. According to Sigelman, the civil servants who try to maximize their bureau budgets are those who are highly devoted to their jobs and believe that government activities are helpful in solving social problems, and those whose positions interact frequently with agency clientele groups.

According to institutionalists, institutions are constraints on human interactions. Institutions also structure human incentive and affect collective outcomes (North 
1990). In addition, several analyses have found that bureaucratic budgeting behaviors or budgetary outcomes are affected by institutions (rules). Ostrom (1986, 3-25) suggested that budgetary outcomes are determined by the configuration of various budgetary rules such as boundary, authority, and aggregation rules. According to von Hargen's view $(2007,27-51)$, an externality that results from using general tax funds to finance targeted public policies, such as policies for constituencies, is at the heart of the common-pool problem of public finances. And Hargen argued that a centralized budgeting process, which promotes agreement on budget guidelines among all actors involved, thereby ensuring fiscal discipline, can induce decision-makers to internalize the externality. A fragmented budgeting process fails to do this. Hargen suggested two basic approaches to centralization of the budgeting process: delegation ${ }^{2}$ and fiscal contracts.

Hsu (1994) analyzed the relationship between Taiwanese institutional contexts and Taiwanese bureaucratic budgeting behaviors, and found that bureaucrats' nonassertive budget requests resulted from both Taiwanese formal institutional contexts (for example, its centralized bureaucratic structure and checks-and-balances-oriented budgeting process) and informal institutional contexts (for example, public interests centered and collective benefits centered Confucian culture), which constrain bureaucratic autonomy and self-interested behaviors while reinforcing public service motivation in the Taiwanese budgeting process. According to Gang's analysis (1999, 189-210) of Korean local governmental budgeting, institutional contexts of local public administration create various motivations, including utilitarianism, public service, and collective benefits, which induce bureaucrats to seek to maximize budgets. Bartle and $\mathrm{Ma}$ (2001) said that budgetary decision-makers, especially elected lawmakers, have a preference for budgetary governance like an entitlement to ensure their commitments will be implemented in the future in uncertain situations.

Up to now, most TDB analyses have theoretically assumed the effects of TDB implementation, or have insisted that TDB should be introduced, or have suggested the directions of its introduction. First of all, many analyses have argued that TDB should be introduced. Schick (2002, 7-48) suggested aggregate financial discipline, allocative efficiency, and operational efficiency as desirable elements of financial management. Focusing on aggregate financial discipline means that, before expendi-

2. The logic of delegation is similar to that of TDB, in that it vests special authority in a fiscal entrepreneur (like a finance minister), whose functions are to set the broad parameters of the budget and to ensure that all other participants in the budgeting process observe constraints. In contrast to this process, a fragmented decision-making process as an incrementalistic method is logically similar to BUB, where the budgeting process starts with the budgets of individual programs. 
ture plans for individual programs are determined, budgetary decision-making for the total budget must be done, which is logically similar to TDB. Some analysts propose TDB as a financial innovation for securing balanced finances, improving the budgeting process, reinforcing performance budgeting, delegating authority to executive agencies and thus ensuring flexibility, assuring operational efficiency, and fostering financial autonomy and responsibility (Shand 1998, 63-88; Bloendal 2003, 7-25; Yun 2003). In looking at the history of American budgetary institutions, LeLoup (1988, 1938) stated that as a result of financial innovations that attempted to address a growing financial deficit after the 1980s, incrementalism and micro-budgeting, which were prevalent until the 1970s, declined, while macro-budgeting and TDB gained ground. There are suggestions that, in order to facilitate the major point of TDB, performance assessment and management systems need to be established (Kim 1998; Kim 2004).

Many researchers have analyzed the theoretical effects of TDB. Ehrhart, Gardner, von Hargen, and Keser (2005) compared TDB with BUB under the situation of incomplete information using the Median Voter Model. They concluded that TDB does not always produce efficiency, because budgetary decision-making is dependent on both budgetary institutions and voters' preferences, so the operation of inefficient budgetary institutions leads to inefficient outcomes, and TDB can not be regarded as more efficient than BUB. Byeon $(2002,112-23)$ predicted that the implementation of TDB in Korea would lead to the exclusion of causes of allocative inefficiencies, the improvement of financial functions to respond to business, the constraint of resource expansion through the control of aggregate funds, the assurance of optimality in budgeting and budget implementation, and other benefits. Kim and Lee (2005) set the budgeting model in informational asymmetry and compared TDB with BUB in terms of efficiency. They argued that TDB is more efficient than BUB under certain conditions. The results of these theoretical analyses conflict with each other.

There has been no deep empirical analysis of the relationship between TDB implementation and its effects. Ryu (2004) and Lee (2006) analyzed the effects of TDB enforcement in Korea in light of various perspectives. The results of their independent analyses are similar. They found that TDB improved the old patterns of excessive budget requests and sharp budget cuts, strengthened executive department autonomy and responsibility, improved allocative efficiency, and reinforced aggregate financial management. At the same time, they indicated the negative effects of TDB, which include the possibility of resource allocation distortion as well as the limits in setting spending ceilings, aggregate fiscal target estimates, and autonomous departmental budgeting. Though Ryu and Lee analyzed allocative efficiency as one of the effects of TDB enforcement, they did not do so in depth, and the allocative efficiency indicators which they selected - setting and observance of spending ceilings, program restructur- 
ing, and relatedness to performance management systems - are not based on theory, nor do they seem to be theoretically valid. They also ignored the institutional diversity of TDB. So their analyses can not tell us what aspects of TDB led to what aspects of outcomes.

\section{METHODOLOGY, APPROACH, AND EXPLANATORY MODEL}

This paper analyzes the relationships between budgetary institutions and outcomes, using the New Institutionalism approach, which focuses on the causal relationship between institutions and collective outcomes. This approach makes it possible to analyze diverse aspects of the relationship between the TDB and allocative efficiencies that have been previously ignored.

In this paper, budgets are regarded as commons. Commons are goods or services with two attributes: nonexcludability and subtractability. Governmental budgets seem to have both of these attributes with regard to departments. Every department has the potential right to request and use the total governmental budget (nonexcludability), and the more a department receives the less there is for others (subtractability). Shepsle and Weingast's budgetary analysis (1984, 343-67)—which explained that budgetary programs determined through legislative political processes, where there exist competitions among constituencies and among committees, tend to have systematic biasesseems to be written from the perspective of commons theories, as does von Hargen's analysis (2007), mentioned above.

Using the commons in the market leads to the tragedy of the commons: market failure. The following approaches have been proposed as solutions to this problem:

(1) The tragedy of the commons can be avoided by government's public control and regulation of the commons (Ophuls 1973; Hardin 1978).

(2) Setting private property rights to the commons can ensure efficiencies in commons-using (Coase 1960; Smith 1981, 467; Welch 1983, 171).

(3) Individuals sharing the commons can solve the dilemma for themselves without intervention by an external entity (Ostrom 1990, 14).

In the case of executive budgeting as a whole, under BUB, in which a department budget request can be made without any preset constraints, every department tends to request ever-increasing budgets, even for useless or invalid programs, in order to get as much funding as possible. This often results in the tragedy of commons: the waste of budget or even governmental financial bankruptcy. By contrast, under TDB, a spending ceiling is set for individual departments or sectors before they start their bud- 
geting process, almost like establishing property rights or use rights to the budgets. Therefore, in TDB, departments do not compete with each other for money, but compete with budgets within the ceiling (their own share) in order to use the budget efficiently, which leads to improved efficiency in budget use.

In budgeting within a department, under TDB, each department has autonomy in budgeting within its own spending ceiling, while under BUB, the central budget office takes the initiative in the budgeting. Thus the implementation of TDB means a situational change from problem-solving by external powers to the form of self-governance that Ostrom (1990) suggested. In the situation of the self-governance, budgeting is conducted by budget users (individual departments), who have more exact information about production skills and processes of public goods or services than an external entity such as the central budget office. Thus, allocative efficiencies can be improved.

These newly introduced situations, establishing budget use rights and self-determination, mean institutional changes in the budgeting process. In order to know what aspects of institutions are changed, and how they might affect outcomes, institutional diversity needs to be analyzed. From this perspective, the IAD framework presented by Ostrom $(1986 ; 2005)$ may be helpful, as it classifies institutions as an exogenous variable into seven diverse rules and analyzes the cause-and-effect paths among the configurations of those rules, action situations, participants' interactions, and outcomes. The explanatory or analytic model of this paper centers on the IAD framework. As shown in figure 1 , budgeting institutional changes due to the implementation of TDB affect the budgeting action situations (and thus individuals' incentives within them), and finally budgeting participants' interactions (behaviors) and allocative efficiencies (budgetary outcomes).

Figure 1. Analytical Model

\begin{tabular}{|c|c|c|c|c|c|c|}
\hline $\begin{array}{l}\text { Top-down budgeting } \\
\text { (budgeting rules) }\end{array}$ & $\rightarrow$ & \begin{tabular}{|c} 
Budgeting \\
action situations
\end{tabular} & $\rightarrow$ & $\begin{array}{c}\text { Interactions } \\
\text { between participants } \\
\text { (behaviors) }\end{array}$ & $\rightarrow$ & $\begin{array}{l}\text { Allocative efficiencies } \\
\text { (budgetary outcomes) }\end{array}$ \\
\hline
\end{tabular}

The changes in both budgeting institutions and action situations caused by TDB implementation will be analyzed according to the seven rules of the IAD framework: position rules, boundary rules, choice rules, ${ }^{3}$ aggregation rules, information rules, payoff rules, and scope rules. ${ }^{4}$ That is, the changes in budgeting institutions and the resulting

3. In Ostrom's earlier papers (1986; etc.), this type of rule has been called "authority rule."

4. Position rules create positions; boundary rules affect how individuals are assigned to or 
changes in action situations will be analyzed using these seven rules. Action situations include such elements as participants, actions, positions, information, control, net costs and benefits, and potential outcomes. How these changes in budgeting rules and action situations cause changes in interactions among bureaucrats as budgeting participants and allocative efficiencies (budgetary outcomes) will be analyzed. The explanation of bureaucratic interactions (behaviors) will focus on the relation between each department and the central budget office, as well as the relations among suborganizations (units) within a department.

Interaction changes will be measured using indicators of the following: rates of budget requirement increases by departments; rates of budget requirement cuts by the central budget office; and rates of executive budget adjustments by the legislature. Since Niskanen (1971) defines bureaucrats as budget maximizers and incrementalists describe them as budget satisficers (Davis, Demster, \& Wildavsky 1966; Wildavsky \& Caiden 2004), the budget requirement increase rate can be used to measure those participants' budgeting behaviors. Budget requirement increase rates for every department are relevant to the measurement indicator for self-interest maximizing behaviors (which cause the tragedy of the commons), because it seems that the higher the rate is, the stronger the appropriation competition is for budgets (as the commons). The results of solving the commons problem may differ depending on whether the solutions feature external control (Ophulus 1973; Hardin 1978) or self-governance (Ostrom 1990). The rates of budget requirement cuts by the central budget office and the rates of executive budget adjustments by the legislature are both pertinent to the measuring indicators for participant interactions (behaviors), because it seems that the higher the two rates are, the larger the external entities' powers are and the stronger their controls are over departmental budgeting. And, because the major problems in the Korean budgeting process until now has been the customs of "excessive requests and huge cuts," these indicators seem to be valid for measuring participant behaviors.

Total budget size, discretionary budget size, and program restructuring size will be used as indicators for allocative efficiency. The public choice theory hypothesizes that bureaucrats guided by self-interest expand public budgets far beyond the optimal level (Niskanen 1971). Therefore, total budget size, which can be a measure of whether

leave positions; choice rules affect the assignment of particular action sets to positions; aggregation rules affect the level of control that individual participants exercise at a linkage within or across situations; information rules affect the level of information available in a situation about actions and the link between actions and outcome linkages; payoff rules affect the benefits and costs assigned to outcomes given the actions chosen; scope rules affect which outcomes must, must not, or may be affected within a domain (see Ostrom 2005: 186-215). 
public budgets are expanded or not, can be used as an indicator of allocative efficiency. Migue and Belanger (1974) depict bureaucrats as maximizers of discretionary budgets, not of total budgets. Thus, discretionary budget size can be an indicator of allocative efficiency. In the Korean budgeting process, meanwhile, bureaucrats have sought to maximize their respective bureau budgets (Gang 1999) through utilitarian motivations, and the TDB was implemented to address that problem. So, the above two indicatorstotal budget size and discretionary budget size — can become valid indicators for efficiency. These two indicators are valid in that, through TDB implementation, the Korean government is trying to induce department program restructuring, thereby making efforts to decrease budget size, especially discretionary budget size.

According to incrementalism, bureaucrats tend to focus on those small changes in the budget derived from current budgets and, as a result, the resulting budgetary outcomes are also small. So, in order to test the theory, the performance of program restructuring by departments was selected as an indicator for allocative efficiency. In the Korean budgeting process under the BUB, which is nominally or partially based on incrementalism, budgetary decision-making had been made piecemeal, focusing on individual programs. TDB implementation is intended to eliminate this irrational customary practice. Thus, the performance of program restructuring may be a good indicator of whether the customary practice was removed or not.

The IAD model includes, as exogenous variables that affect participants' action situations and incentives, rule configurations as well as biophysical/material conditions and attributes of community (Ostrom 2005). However, in the analytical model of this paper, biophysical/material conditions and attributes of community were omitted because biophysical/material conditions, which are important variables in the study of natural resources, are not crucial in budgetary decision-making. In this paper, attributes of community are assumed not to be in favor of collective action, in that many departments participate in the budgeting process, and so the size of the community is very big and the attributes of its members are very heterogeneous. Above all, the main reason the two variables were omitted was that their attributes did not change after the implementation of TDB.

Based on this explanatory model, this paper will first specifically describe how budgeting institutions and action situations changed due to the implementation of TDB. Then it will examine the resulting changes in budgeting participant interactions and allocative efficiencies. Finally, it will assess whether the changes in the efficiencies are affirmative or negative based on Korean budgeting situations.

The period of analysis is from fiscal year 2001 to 2007. Budgeting rules and budgetary outcomes of FY 2001 through 2004, prior to implementation of TDB, will be compared with those of FY 2005 through 2007, following the implementation of the 
system. This paper will focus on the executive budgeting process, in that Korean TDB focuses on changes in the executive decision-making process and is not related to the legislature approval phase.

\section{BUDGETING INSTITUTION CHANGES}

\section{Overview}

The TDB in Korea was implemented by four agencies as pilot cases in the FY 2004 budget: the National Tax Service, Customs Service, Fair Trade Commission, and Public Procurement Service. Since the FY 2005 budget, TDB has been implemented by almost all forty-eight departments, with the exception of five independent agencies (the National Assembly, Supreme Court, Constitutional Court, National Election Commission, and Board of Audit and Inspection).

\section{Changes in Budgeting Rules and Action Situations}

\section{Position Rules and Positions}

Under BUB, executive budgeting took place in two phases: (1) the budgeting of individual programs and the submission of budget requests by departments, and (2) the budget requirement review and adjustment by the central budget office, the Ministry of Planning and Budget (MPB). The major positions in this process include the departments and their budget offices and suborganizations, the MPB, and the president.

Under TDB, there are three executive budgeting phases: (1) setting the aggregate fiscal target and the spending ceilings by MPB, (2) autonomous budgeting and budget requests by departments, and (3) budget requirement reviews by MPB. The positions assigned to those budgeting phases are the MPB, the expert advisor groups, the National Resource Allocation Council, the departments and their suborganizations and budget offices, stakeholder groups, and so on. The National Resource Allocation Council and the expert advisor groups are added positions newly formed with the introduction of TDB.

\section{Boundary Rules and Participants}

The heads of both the MPB and departments are nominated by the president, and their staffs are national public service personnel. The National Resource Allocation Council is assigned by the president (who is elected by the people) and the state ministers (who are nominated by the president). The expert advisor groups are assigned by 
the staffs of related departments, researchers in government institutions, university professors, and staff members of the Bank of Korea (the central bank).

\section{Choice Rules and Actions}

The choice rules and actions were changed with the TDB. Under BUB, decisionmaking started from the bottom, the line departments. At the first stage, departments submitted their budget requests program by program to the MPB. The MPB then reviewed and adjusted the requirements, and then a national budget for total expenditure was made by aggregating the departmental budgets. In this budgeting process, the MPB had the real and final rights for budgetary decision-making. And if the budget of a program had to be cut, the total budget would have to be cut, since the budget was predicated upon each program. The MPB, with absolute power of budget review, took the initiative in budgeting (Ministry of Planning and Budget 2005b: 135).

Under TDB, budgetary decision-making starts from the top, the central budget office. Aggregate fiscal targets etc. are first determined by the MPB, which sets the spending ceiling for each department; each department then makes a budget request and submits it to the MPB for review. To look at these procedures in more detail: At the first stage, the MPB takes the role of determining aggregate fiscal targets (macroeconomic prospect, revenue size, demand for expenditure, and so on), setting spending ceilings, and writing general executive budgeting guidelines, all of which are made a part of the National Fiscal Operational Planning. Then, at the second stage, each department, exercising its autonomy and expertise, makes budgetary decisions regarding its programs within the spending ceiling. In the third phase, the MPB reviews each budget and assesses both whether or not the department observed the spending ceiling and executive budgeting guidelines and its performance in program restructuring. Thus, the departments' autonomy and rights in the budgeting process have increased substantially. In the phase of making an aggregate fiscal target, the National Resource Allocation Council determines the basic direction of resource allocation. The expert advisor groups give advice on the formation of the National Fiscal Operational Planning, and the public can voice its opinion through public forums (Lee 2006: 24-95). Under both BUB and TDB, the president's intentions, as chief executive, are put into the process through the MPB.

As departments gained more autonomy, the department budget officer's role became increasingly significant. After TDB implementation, in budgeting within a department, the budget officer became budget reviewer and the staff in charge of programs at the suborganization level became budget advocates. Under BUB, the department budget officer took the passive role of delivering information between the department and the central budget office, but under TDB, the budget officer takes a 
much more active role. In the stage at which spending ceilings are established, the budget officer should gather and analyze information and then try to get approval for as high a spending ceiling as possible. In the departmental budgeting phase, the budget officer also has to establish priorities among department programs, organize opinions among both suborganizations and external stakeholders, and fix the budget.

\section{Aggregation Rules and Control}

In executive budgeting under BUB, the MPB, as the president's agent, exercised very powerful control rights. After every department budget request was submitted to the MPB, that agency took the final step and fixed the executive budget through huge budget cuts or adjustments. In this situation, budgeting within the department was not recognized as important. Therefore, under BUB, budgeting based on Korean incremetalism was very centralized, contrary to incrementalism defined by Wildavsky (1988), et al. 5

Since the implementation of TDB, the basic framework for national resource allocation has been determined by the spending ceiling initiated by the MPB. The MPB refers to mid-term financial plans submitted by every department, and then sets the ceiling scheme based on conferences with related organizations. The ceiling scheme is finally fixed by the National Resource Allocation Council, presided over by the president. In the process, the authority of the MPB is substantial, while department control is too weak. The president, who has the primary responsibility for executive budgeting, conveys his intention to the MPB. The MPB, in turn, assures that these intentions are realized, just as under BUB.

The relative control exercised by each participant in the decision-making process within a department has been significantly changed. Under BUB, real control of the program-making process within a department was exercised by the MPB. Since the introduction of TDB, however, every department has the right to make its own budgetary decisions within the spending ceiling. In the budget-making process of each department, budget officers exercise core control. The budget officer synthesizes and organizes budget requests submitted by suborganizations, and then makes the department's final requests. Every department budget request prepared through those processes will be approved without any major changes in the phase of review by MPB, as long as it observes the spending ceiling. 6

5. From this perspective, under BUB, Korean governmental budgeting was based not on typical incrementalism but on a transformed version.

6. Whereas top-down systems are generally thought to be more centralized and authoritarian, TDB in Korea is actually a more decentralized, and therefore more democratic system of 


\section{Information Rules and Information}

Under BUB, aggregate fiscal targets, which include macroeconomic prospects, total budget size, and other factors, were created internally and managed informally and privately by MPB (Kim 1999, 80-84). In the review of budget requests submitted by every department, resource allocation was made from the independent view of the MPB, as well as secret MPB briefings to the president, based on each department's proposal. Thus, there was no opportunity for communication or discussion among the departments, nor was there any voicing of or sensitivity towards public demands.

With the implementation of TDB, National Fiscal Operational Planning, which includes budgets, is carried out in advance every five years. The planning is made to overcome any limits in short-sighted annual budgeting based on the mid- and long-term perspective, and also to improve the efficiencies of financial operations by creating a connection between policies and budgets (Ministry of Planning and Budget 2004, 34). The planning suggests annual aggregate fiscal targets (estimation of revenues and expenditures, national liabilities, and so on), the spending ceiling for the department, and specific resource allocation plans for each program. It gives basic guidelines for the following year's budgeting and the plan of fund operations.

The determination of aggregate fiscal targets and the setting of a spending ceiling, which are two component processes of National Fiscal Operational Planning, are made by the MPB, based on the mid-term fiscal plans submitted by the departments. They are also made publicly through conferences of related organizations, the advice of experts, and public hearings. Aggregate fiscal targets and spending ceilings made through these processes are finally fixed by the National Resource Allocation Council. A spending ceiling is set at four levels: per department, per sector (large classifications-there are 14 sectors in National Fiscal Operational Planning), per area (middle classifications - there are 56 areas in National Fiscal Operational Planning), and per account within the department. The spending ceiling is set including general accounts, special accounts, and funds.

In the executive budgeting process, communication among departments becomes possible through discussions among state ministers in the National Resource Allocation Council. The public demands can be placed into the process through public hearings. In setting the spending ceiling, MPB should confer with each department. Any compromise between them is formed through the budgeting guidelines, delivered from MPB to each department, and the mid-term program plan, submitted by each department to MPB.

budgeting that empowers individual departments to have a voice in the process of resource allocation. 
The major contents of the budgeting guidelines, which are introduced with the TDB, contain the following: each department's autonomous budgeting within its spending ceiling, each department's autonomous assessment of programs, a review of program priorities, and self program restructuring etc. According to these guidelines, communications within the department become much more active. That is, the report to the minister or vice-minister and incorporating the opinions from each suborganization become much more frequent (Lee 2006, 110). Since each department performs its own budgeting autonomously, the respective departments come to reach decisions with more exact information, and through more active delivery of the information within the department. The department budget proposal, which is made based on these guidelines and whose contents reflect the details and size of budgets as well as the performance of program restructuring, is submitted to MPB.

\section{Payoff Rules and Costs/Benefits}

In the review phase of each department budget proposal, the MPB investigates whether or not the budgeting guidelines were observed by the department and offers the department incentives based on the review. For those departments that observed the guidelines, their programs are reviewed only once, and even if a part of a budget is cut, it can be used by other programs within the spending ceiling. For those departments that did not observe the guidelines, their programs are reviewed specifically for individual programs by the BUB method. The priority and validity of the programs are then reviewed, and the budgets are cut accordingly and then organized below the spending ceiling.

In order to induce the downsizing of total and discretionary budgets, incentives are given to departments for program restructuring. Departments that effectively perform restructuring are given the following incentives: an increase in the basic budget of programs, a positive reflection in the department works evaluation, recognition for excellence, and, as much as possible, reflection of the opinions of that department in budget conferences. On the other hand, the department that performs poorly is provided with negative incentives, such as additional program restructuring in the budgeting conference and disadvantages in determining the basic budget of programs (Lee 2006, 129).

\section{Scope Rules and Outcomes}

After the implementation of TDB, the MPB induces each department to restructure its programs by prescribing the following items in the budgeting guidelines: the department's autonomous budgeting within the spending ceiling, the autonomous assessment of programs, the review of program priorities, and self-program restructuring (Lee 2006, 126-37). The rules of program restructuring seek to constrain the size 
of the total and discretionary budgets by preventing moral hazards as well as adverse selections due to the department's autonomous budgeting. These rules also control the misuse of autonomous budgeting by the departments and those biased budgeting efforts that center on preferential programs (discretionary budgets) in order to constrain the size of those budgets. The object of the restructuring performance assessment by MPB is restricted to those discretionary expenditures that are preferred by the department. However, the entitlements are excluded from the object, because the expenditure obligation and other details of the entitlements are prescribed by law and thus the department can hardly decrease the size and the production cost of programs in entitlements (Ministry of Planning and Budget 2005a, 9). As a result, it seems that rules about program restructuring seek especially to decrease the size of the discretionary budget.

\section{EFFICIENCY CHANGES}

\section{Interaction Changes}

Until now, the most severe problem in Korean budgeting has been allocative inefficiency due to the pattern of excessive budget requests by departments and huge budget cuts by MPB (Byeon 2002; Ryu 2004; Lee 2006). This phenomenon can be seen as the tragedy of the commons caused by bureaucratic budget-maximizing behaviors. The changes in the interaction of budgeting participants can be analyzed in order to identify whether or not allocative inefficiency was cured by the implementation of TDB, which sets quasi-property rights to the budget as a commons. Table 1 shows three factors in this analysis: rates of budget request increase by department, rates of budget requirement cuts by the MPB, and rates of executive budget adjustments by the National Assembly.

The ratio of budget request increases to the previous fiscal year budget, which was made by each department, significantly decreased in both general accounts and special accounts after the implementation of TDB. In addition, the ratio in special accounts was negative, which means a decrease in budget requirements compared to the previous fiscal year special accounts. As for the total budget, including both general accounts and special accounts, the ratio decreased from about 30 percent before TDB to 5 to 9 percent after TDB.

These results suggest that the implementation of TDB constrained the departments' bureaucratic budget-maximizing behaviors. That is, the configuration of seven changed budgeting rules controlled those opportunistic behaviors of department 
Table 1. Rates (\%) of Budget Request Increases, Budget Cuts, and Budget Adjustments by Fiscal Year

\begin{tabular}{|c|c|c|c|c|c|c|c|}
\hline & 2001 & 2002 & 2003 & 2004 & 2005 & 2006 & 2007 \\
\hline \multicolumn{8}{|c|}{ Rates of budget request increases by departmentsa } \\
\hline General account & 37.3 & 38.2 & 24.7 & 29.7 & 16.0 & 10.6 & 14.0 \\
\hline Special account & 21.5 & 18.4 & 34.2 & 15.8 & -2.3 & -3.2 & -16.5 \\
\hline Total & 30.3 & 30.0 & 28.4 & 24.3 & 9.4 & 6.3 & 5.4 \\
\hline \multicolumn{8}{|c|}{ Rates of budget cuts by MPB } \\
\hline General account & 25.1 & 22.1 & 18.3 & 23.4 & 4.4 & 2.0 & 4.5 \\
\hline Special account & 23.9 & 14.7 & 28.1 & 22.3 & 2.9 & 2.2 & 8.0 \\
\hline Total & 24.6 & 19.2 & 22.1 & 23.0 & 3.9 & 2.1 & 5.3 \\
\hline \multicolumn{8}{|c|}{ Rates of budget adjustments by the legislaturec } \\
\hline General account & 0.9 & 0.6 & -0.2 & -0.7 & -2.1 & 0.6 & 0.9 \\
\hline Special account & 0.4 & 0.4 & 0.0 & -0.1 & 6.0 & 0.3 & -0.3 \\
\hline Total & 0.7 & 0.5 & -0.1 & -0.5 & 0.4 & 0.5 & 0.7 \\
\hline
\end{tabular}

Source: The ministry of Planning and Budget, Annex to Summary of Budget (2001-07).

a: [(Department requirement-preFY budget)/preFY budget $]^{*} 100$

b: [(Department requirement-Executive budget)/Executive budget] ${ }^{\star} 100$

c: [(Executive budget-approved budget by Legislature)/ approved budget by Legislature $]^{\star} 100$

bureaucrats which compete for appropriation of budgetary funds as the commons. The National Resource Allocation Council (position rule change) made it possible for prime policy-makers, including the president and ministers, to attend the phase where the aggregate fiscal target and the spending ceiling are set (boundary rule change), understand the positions of other departments, and organize the interests among departments in advance. Also, the Council prohibited prime policy-makers from insisting on only their department's position. Setting the spending ceiling by the MPB and budgeting by department bureaucrats within the ceiling (choice rule change) made it difficult for them to request excessive budgets. Through writing a mid-term fiscal operational planning, objective information about the fiscal statistics and the direction of budget review should all be open to the public, and mid- and long-term viewpoints should be reflected in the budgeting process (information rule change), so that departmental opportunistic behavior becomes more difficult. Bureaucratic budget-maximizing behavior was controlled, and efficient decision-making based on exact information within the department was induced. This is because, while the department received autonomous and real decision-making rights to make its budget within a spending ceiling (aggregation rule change), it received affirmative or negative incentives regarding both its observance of the ceiling and budgetary outcomes (payoff rule change), and it had the responsibility for budgetary outcomes by assessing the performance of 
program restructuring (scope rule change).

The rate of department budget requirements cut by the MPB decreased substantially in both general and special accounts. In the total budget, the rate decreased from about 20 percent to about 2 to 5 percent, which means that each department's budget proposal was mostly reflected in the executive budget without large amendments after the TDB implementation. These phenomena were the result of constraints on bureaucratic budget-maximizing behavior due to the changes of choice rules, information rules, payoff rules, and so on.

The rate of the executive budget adjustment by the National Assembly was very small, regardless of the implementation of TDB. In the total budget, the ratio was below the absolute value 1, meaning the executive budget was either decreased or increased by less than 1 percent by the legislature. This resulted from the fact that the TDB in Korea is only related to the executive budgeting rules, but not to the National Assembly's budget review.

It appears that the problematic budgeting behaviors of excessive requests and huge cuts were diminished by the implementation of the TDB. As evaluated by the changes in the behaviors, allocative inefficiency caused by budget-maximization appears to have decreased.

\section{Efficiency Changes}

\section{Total Budget Size}

As discussed above, the implementation of TDB changed the behaviors of budgeting participants. In order to analyze whether or not these behavioral changes have led to changes in allocative efficiencies (budgetary outcomes), it is necessary to look at the ratio of budget to GDP in order to analyze the changes of total budget size. As shown in table 2, the ratio of general accounts to GDP slightly increased from about 15 percent before TDB to 17 percent after TDB. In contrast, the ratio of special accounts (net total) to GDP decreased from about 10 percent to 4-7 percent. The ratio to GDP of the total budget, which includes both the general budget and the special budget, decreased from about 25 percent to $21-23$ percent. These results suggest that the reduction of budget-maximizing behavior due to the implementation of TDB resulted in the downsizing of the governmental budget. As Shepsle and Weingast (1984) argued, it is difficult to know whether the size of a governmental budget is too large or too small. However, considering the public choice theorists' hypothesis that bureaucratic budget-maximizing behavior causes excessive expansion of public budgets beyond the optimal level (Niskanen, 1971), the decreases in both the maximizing behavior and budget size seem to be desirable, and allocative efficiencies seem to 
Table 2. Ratio (\%) of Budget to GDP by Fiscal Year

\begin{tabular}{l|r|r|r|r|r|r|r}
\hline & 2001 & 2002 & 2003 & 2004 & 2005 & 2006 & 2007 \\
\hline General account & 15.1 & 15.5 & 15.4 & 15.2 & 16.6 & 17.1 & 17.3 \\
Special account & 10.4 & 9.8 & 9.7 & 8.4 & 7.3 & 6.6 & 4.3 \\
Total & 25.5 & 25.2 & 25.1 & 23.6 & 23.8 & 23.7 & 21.6 \\
\hline
\end{tabular}

Source: The Ministry of Planning and Budget, Summary of Budget (2001-07); Annex to Summary of Budget (2001-07).

* In the case of GDP, FY 2001-2006 used settlement and FY 2007 used budget.

improve.

It appears that these results, as discussed above, are due to the fact that the changes in the configuration of budgeting rules caused by TDB had an effect on the interactions between every department and the MPB, and thus constrained the bureaucratic opportunistic behavior that seeks to maximize department budgets.

\section{Discretionary Budget Size}

Migue and Belanger (1974) argued that bureaucrats seek to maximize their bureau's discretionary budgets instead of unconditionally maximizing outputs (budgets). Since bureaucratic discretionary budget-maximizing behavior may also cause allocative inefficiency, the changes in discretionary budget size due to TDB need to be analyzed. ${ }^{7}$

As shown in table 3 , the ratio of current expenditures (goods and services expenses) to total budget (general accounts) was reduced from about 10 percent before TDB to about 8 percent after TDB. Also, the ratio of capital expenditures (investment project expenses) to total budget decreased from about 9 percent to about 7 percent. The ratio of total discretionary budgets, which include goods and services expenses and capital expenditures, decreased from about 19 percent to 15 percent. Since seeking discretionary budgets means pursuing self-interest through managerial discretion and oppor-

7. Discretionary budgets are expenditures from which entitlements (obligatory expenses) are excluded and which include investment project expenses and current expenses. In this paper, discretionary budgets include both capital expenses as major investment project expenses and current goods and services expenses, which are composed of expenses incurred with a high amount of departmental discretion, such as office operations, special operations, and management expenses. However, of the current expenditures, personnel expenses (whose expenditure guidelines and other details are rigidly specified by law and thus whose discretion is very low) were excluded. For information about classificatory distinctions under TDB between entitlements and discretionary expenditures (which are the object of program restructurings), see Ministry of Planning and Budget (2005c). 
tunistic behavior, the decrease in size seems to be desirable from the perspective of allocative efficiency. It is debatable whether the ratio reduction of capital expenditure as investment project expenditure is desirable or not. However, as discussed below in the section on program restructuring, in discretionary programs (budgets), affirmative outcomes occurred such as the end or mergence of inefficient programs. Thus, the decrease of capital expenditure ratio seems to be desirable.

Table 3. Ratio (\%) of Discretionary Budget to Total Budget by Fiscal Year (General accounts)

\begin{tabular}{l|r|r|r|r|r|r|r}
\hline & 2001 & 2002 & 2003 & 2004 & 2005 & 2006 & 2007 \\
\hline Goods and services expense & 11.1 & 10.4 & 10.8 & 7.9 & 7.6 & 7.9 & 8.1 \\
Capital expenditure & 9.0 & 8.4 & 8.5 & 9.3 & 7.4 & 7.3 & 6.8 \\
Total & 20.1 & 18.9 & 19.4 & 17.2 & 15.0 & 15.1 & 14.9 \\
\hline
\end{tabular}

Source: Ministry of Planning and Budget, Summary of Budget (2001-07); Annex to Summary of Budget (2001-07).

As discussed above, these changes in budgetary outcomes may have resulted from the fact that the changes in the configuration of budgeting rules constrained bureaucrats' opportunistic behaviors in budgeting and made them take responsibility for the budgetary outcomes.

In relation to the behavior of discretionary budget-seeking, the changes of special account size need to be analyzed. In Korea, since special accounts and funds have been excessive, problems of both the complexity of budget systems and efficiencies have occurred. Since partitioned mechanisms, such as special accounts and funds, give a department managerial discretion and the possibility for opportunistic behaviors to a much greater extent than do general accounts, they have been excessively increased by bureaucrats' efforts to maximize their discretionary budgets (Yun 2007). TDB sets a spending ceiling for departments, including general accounts as well as special accounts and funds (choice rule change). It also gives the department budgeting autonomy within that ceiling (aggregation rule change). Now, therefore, those partitioned mechanisms have become bothersome and are no longer advantageous to the department. Thus, the size of special accounts is expected to decrease.

As shown in table 4, with the implementation of TDB, the ratio of special accounts (net total) to total budget significantly deceased from 40.7 percent (FY 2001) to 19.8 percent (FY 2007). As discussed above, both the special account request increase rate by the department and the ratio of special accounts to GDP also substantially decreased (see table 1 and table 2). This indicates that special accounts are no longer advantageous to the departments' managerial discretion and opportunistic behavior 
Table 4. Ratio (\%) of Special Accounts to Total (General + Special) Budget by Fiscal Year

\begin{tabular}{l|l|l|l|l|l|l}
\hline 2001 & 2002 & 2003 & 2004 & 2005 & 2006 & 2007 \\
\hline 40.7 & 38.7 & 38.5 & 35.7 & 30.5 & 27.9 & 19.8 \\
\hline
\end{tabular}

Source: The Ministry of Planning and Budget, Summary of Budget (2001-07); Annex to Summary of Budget (2001-07).

due to the changes in choice rules and aggregation rules. Thus, the departments' request rate for special accounts, as well as the resulting size of special accounts, also decreased. These results indicate a reduction of the discretionary budget. Thus, the results seem to be desirable. These results also suggest that allocative efficiency was improved, considering that before TDB in Korea, budgetary inefficiencies and complexities due to the excessive installation of special accounts were severe problems.

\section{Program Restructuring Size}

According to incrementalists, budget-makers try to attain marginal changes in budgetary decision-making based on the current fiscal year budget (Davis, Demster, \& Wildavsky 1966; Wildavsky \& Caiden 2004). In this situation, it is very difficult to expect significant innovations or changes, and if past resource allocation had been inefficient, this inefficiency would possibly continue. In Korea, the main purpose of implementing TDB was to abandon the customs of policy-making based on BUB, whose logic is in line with that of Korean incrementalism. Another purpose of TDB was to allocate resources more efficiently. The effects of TDB can be measured by assessing the performance of program restructuring.

Table 5. Extent of Restructuring of Continued Programs and Establishment of New Programs (in trillion won)

\begin{tabular}{l|c|c|c}
\hline & $\begin{array}{c}\text { FY 2004 } \\
(\mathrm{A})\end{array}$ & $\begin{array}{c}\text { FY 2005 } \\
(\mathrm{B})\end{array}$ & $\begin{array}{c}\text { Increase/decrease } \\
(\mathrm{B}-\mathrm{A})\end{array}$ \\
\hline Extent of restructuring of continued programs & -1.6 & -2.7 & -1.1 \\
(Number of programs) & $(-312)$ & $(-409)$ & $(-97)$ \\
\hline Budgets for new programs & 1.5 & 3.0 & 1.5 \\
(Number of programs) & $(345)$ & $(468)$ & $(123)$ \\
\hline
\end{tabular}

Source: Ryu 2004, 89.

* Naturally decreasing amounts excluded in the restructuring of continued programs.

The restructuring (downsizing) of continued programs significantly increased from 1.6 trillion won in FY 2004 to 2.7 trillion won in FY 2005, and the budget for new 
programs was doubled from 1.5 trillion won to 3.0 trillion won in the same period (see table 5). These changes indicate that departments carried out positive program restructuring by actively ending, downsizing, or merging continued programs based on an evaluation of program validity or implementation performance and by investing the resulting residual resources in new programs.

As shown in table 6, after the implementation of TDB, the performance of program restructuring in the area of discretionary expenditures increased. The rate of restructuring increased substantially from 5.6 percent in FY 2005 to 9.7 percent in FY 2007. This seems to have resulted from the facts that in the process of expenditure restructuring, similar or redundant programs were ended or merged, and for programs that received unsatisfactory ratings in department self-assessments, over 10 percent restructuring target of the previous fiscal year's budget was cut or instructions from external agencies such as the National Assembly and the Board of Audit and Inspection were actively reflected in the budget, thereby improving the efficiency of expenditures (Ministry of Planning and Budget 2007).

Table 6. Performance of Expenditure Restructuring (in trillion won)

\begin{tabular}{l|c|c|c}
\hline & FY 2005 budget & FY 2006 budget & FY 2007 budget \\
\hline Expenditure of restructuring programs & 42.7 & 44.8 & 47.2 \\
Performance of restructuring & -2.4 & -4.2 & -4.6 \\
Rate of restructuring (\%) & 5.6 & 9.3 & 9.7 \\
\hline
\end{tabular}

Source: Ministry of Planning and Budget 2007, 58.

a: Naturally completed or decreased programs were excluded from the previous fiscal year's total discretionary expenditure.

Through the program restructuring, continued programs with low validity or performance decreased, while new programs increased. This result might indicate that the problem of inefficiencies in the budgeting process based on the logic of Korean incrementalism under BUB was more or less solved. These performances resulted directly from the fact that, with the introduction of TDB, changes in the configuration of budgeting rules changed budgeting participants' behaviors. More specifically, these performances came from the following budgeting rule changes: while the MPB set the department's spending ceiling (choice rule change) and allowed every department to exercise real budgeting rights within that ceiling (aggregation rule change), it made departments responsible for budgetary outcomes by giving them incentives based on an evaluation of their program restructuring (scope and payoff rule change). 


\section{DISCUSSION AND CONCLUSION}

Under BUB in Korea, fragmented and individual program-centered budgeting behaviors, which incrementalism describes, occurred. However, the actual rights for budgeting were substantially centralized in the central budget office. Allocative inefficiencies caused by budget-maximizing behavior, which public choice theory describes, also occurred. Starting in FY 2005, the Korean central government implemented TDB in order to cure these problems. This paper focused on the effects of the implementation of TDB on the allocative efficiencies (budgetary outcomes) in Korea. Defining budget as the commons, and using the perspective of New Institutionalism (especially the IAD model), which has been used to analyze the commons problems, this paper comparatively analyzed situations before and after TDB implementation.

First, using the seven rules of the IAD model, changes in both budgeting rules and the resulting action situations due to the implementation of TDB were analyzed. The major institutional changes due to TDB are as follows: the MPB (central budget office) sets departments' spending ceilings in advance; every department makes its own budget within the ceiling (choice rule change); and, every department has autonomous and real rights in regards to its own budgeting (aggregation rule change). One of the most important institutional changes is that while giving every department real budgeting rights, the MPB also gives them incentives based on an assessment of (1) the degree to which they observed budgeting guidelines and (2) the performance of program restructuring (budgetary outcomes) in the review phase of the department's budget request (payoff and scope rule change).

Second, an analysis was done as to whether or not the changes in the configuration of budgeting rules had effects both on budgeting participants' interactions and on the resulting allocative efficiencies. The analysis found that, in interactions between MPB and departments, the rate of budget request increases by the departments significantly decreased, and thus the rate of budget cuts by the MPB was significantly reduced. Due to these behavioral changes, budgetary outcomes were also changed. The ratio of the government's total budget to GDP, and the ratio of discretionary budget to total budget, were decreased, and the performance of discretionary expenditure restructuring (continued program cutback and new program enlargement) increased. Thus, allocative efficiencies seem to be improved.

It seems that the institutional changes due to the implementation of TDB can be classified in three ways. First, in the budgeting of the whole national unit, setting spending ceilings for every department and sector by the central budget office is analogous to setting quasi-property rights or use rights for a governmental budget which 
has the attributes of the commons. If the use rights (shares) are set for each department, each department will try to maximize the utility from its share rather than seeking to appropriate as much of the national budget as possible through budget-maximization. This seems to be the reason that desirable changes in budgetary outcomes have appeared since the implementation of TDB. These changes include the reduction of excessive budget requests and the cutback of both total budget and discretionary budget.

Second, in budgeting within a department, each department exercises real budgeting rights, in that it can autonomously perform budgetary decision-making within the spending ceiling set by the central budget office. This means that the decision-making type of budget as a commons has changed from budgeting by an external entity (central budget office) to budgeting by the users (departments) themselves. The problems of commons which are used by a small community tend to be more efficiently managed by users themselves, who have exact information about their commons, than by and external entity (Ostrom 1990). This situation is similar to budgeting within a department. That is, budgeting by a department itself, which has more exact and sufficient information about its programs as well as the productive costs of its goods or services, may be more efficient than budgeting by the central budget office, which does not possess exact and sufficient information about departmental programs. As discussed above, in practice, after the implementation of TDB, the actualization of information delivery and communication in budgeting within the department, and the more desirable budgetary outcomes, seem to be the result of these facts.

Third, in budgeting within a department, there exists an informational asymmetry between the department and the central budget office. In this situation, budgeting by the central budget office has the possibility of moral hazards and adverse selections. That is, every department provides the central budget office with information distorted or advantageous to itself, and thus the central budget office, which has inexact and inefficient information, can have difficulty in allocating resources rationally. TDB can address the problem of informational asymmetry by introducing incentive systems based on the assessment of budgetary outcomes. That is, the central budget office can induce efficient resource allocation by giving the departments both autonomous budgeting rights and affirmative or negative incentives based on assessment of budgetary outcomes. In spite of the department's autonomous budgeting, cutback of discretionary budget and actualization of program restructuring could be possible through incentive systems.

Despite the fact that TDB led to these desirable outcomes, several problems exist and several reform measures are possible. First, setting an effective spending ceiling is the key to the success of TDB. If the ceiling is too high or too low, however efficiently 
the department allocates resources within its scope, allocative efficiency cannot be achieved. In the phase of spending ceiling setting, in addition to submission of a midterm program plan by every department, a procedure of meeting that the head of every department can attend should be formed (position rule improvement), or every department head should attend the existing National Resource Allocation Council (boundary rule improvement). The methods, such as the development of objective indicators, that help to rationally set the spending ceiling, need to be made, through a more specific definition of allocative efficiency (information rule improvement).

Second, TDB in Korea is currently focused more on choice rules (specification of actions) than scope rules (specification of outcomes). While allowed to autonomously conduct budgetary decision-making, the department should accept greater responsibility for its budgetary outcomes. Though now the outcomes are assessed on the basis of the amount of restructuring, an increase in the amount of restructuring is not always desirable. Thus, an evaluation of the contents of the restructuring, such as program validity, needs to be carried out at once (scope rule improvement). To do so, when submitting budget requests, every department should submit objective data that help to prove the validity of restructuring (information rule improvement). In addition to program restructuring, assessments should be performed of various other aspects. Through direct assessment of the size of both the department's total budget and its discretionary budget (scope rule improvement), and based on the results of assessment, an affirmative incentive should be given to departments that budgeted more economically or efficiently (payoff rule improvement). In order for this to happen, the concept of allocative efficiency and its assessment measures need to be specifically prescribed in the budgeting guidelines that are delivered to all departments (information rule improvement).

\section{ACKNOWLEDGMENTS}

This is a revised version of a paper (An Analysis of the Relationship between Budgeting Institutions and Efficiencies) presented at the Y673 Seminar Fall 2007 MiniConference (Monday, December 10), Workshop in Political Theory and Policy Analysis, Indiana University. The author would like to thank all workshoppers for their helpful discussions and comments. 


\section{REFERENCES}

Abney, G., \& T. P. Lauth. (1989). The executive budget in the states: Normative idea and empirical observation. Policy Studies Journal, 17(4): 829-40.

Auster, R. (1975). Some economic determinants of the characteristics of public workers. In R. G. Sirkin (Ed.), Economics of public choice. New York: Cycero Press.

Bae, D. J. (2004). Wider application of theory of the commons. Korean Public Administration Review, 38(4): 147-57.

Bartle, J. R., \& J. Ma. (2001). Applying transaction cost theory to public budgeting and finance. In J. R. Bartle (Ed.), Evolving theories of public budgeting. Oxford: Elsevier Science.

Bendor, J., \& T. M. Moe. (1985). An adaptive model of bureaucratic politics. The American Political Science Review, 79(3): 755-744.

Bloendal, J. R. (2003). Budget reforms in OECD member countries: Common trend. OEDC Journal on Budgeting, 2(4): 7-25.

Byeon, Y. K. (2002). Three essays on the sustainability of government finances and improving efficiency in resource allocation in Korea. Dissertation, Sogang University.

Calvert, R. L., M. D. McCubbins, \& B. R. Weingast. (1989). A theory of political control and agency discretion. American Journal of Political Science, 33(3): 588611.

Coase, R. H. (1960). The problem of social cost. Journal of Law Economics, 3.

Davis, O. A, M. A. Demster, \& A. Wildavsky. (1966). A theory of political control and agency discretion. The American Political Science Review, 60(3).

Ehrhart, K. M., R. Gardner, J. von Hargen, \& C. Keser. (2005), May. Budget processes: Theory and experimental evidence. ECPR Discussion Paper No. 2661, http:// www.cepr.org/pubs/dps/DP2661.asp.

Forrester, J. P. (2001). Public choice theory and public budgeting: Implications for the greedy bureaucrat. In J. R. Bartle (Ed.), Evolving theories of public budgeting (pp. 101-124). UK: Elsevier Science Ltd.

Gang, Y. (1999). Bureaucrats' motivations and budget-maximizing behaviors in Korean local governmental budgeting. Korean Public Administration Review, 33(4): 189-210.

Hardin, G. (1978). Political requirements for preserving our common heritage. In H. P. Bokaw (Ed.), Wildlife and America. Washington, DC: Council on Environmental Quality.

Hsu, J-H. (1994). Institutions and bureaucratic behavior in budgeting: The case of Taiwan. Dissertation, University of Southern California. 
Kelman, M. (1988). On democracy bashing: A skeptical look at the theoretical and empirical practice of the public choice movement. Virginia Law Review, 74.

Kim, G. L. (1999). An analysis on the budgeting process in Korea. Dissertation, Kyeonghee University.

Kim, I. S. (2004). Top-down budget: Economic issues. Korean Journal of Public Policy, 6.

Kim, J., \& K. Lee. (2005). An analysis on the budgetary institution in informational asymmetry. Korean Association for Public Finance and Economics fall seminar papers.

Kim, S. H. (1998). Microeconomic analysis of informational asymmetry in budgeting. Korean Public Administration Review, 32.

Kraan, D-J. (1996). Budgetary decision: A public choice approach. New York: Cambridge University Press.

Lee, K. (2006). The change in decision-makers' behavior and performance as a result of the new top-down budget system in Korea. Dissertation, Seoul National University.

Leloup, L. T. (1984). Appropriations politics in Congress: The House Appropriations Committee and the executive agencies. Public Budgeting and Finance, 4(4): 78-98.

. (1988). From microbudgeting to macrobudgeting: Evolution in theory and practice. In I. S. Rubin (Ed.), New directions in theory (pp. 19-38). Albany: SUNY Press.

Leloup, L. T., \& W. B. Moreland. (1978). Agency strategy and executive review: The hidden politics of budgeting. Public Administration Review, 38(3): 232-39.

Margolis. (1975). Comment on Niskanen bureaucrats and politicians. Journal of Law and Economics, 18: 645-59.

Markris, M. (2006). Political authority, expertise and government bureaucracies. Public Choice, 127(3-4): 275-92.

Migue, J., \& G. Belanger. (1974). Toward a general theory of managerial discretion. Public Choice, 17: 24-43.

Ministry of Planning and Budget. (2004). Basic plan for national resource allocation improvement. . (2005a). FY 2006 detailed guidelines for budgeting.

. (2005b). Budgetary work manual. . (2005c). Internal documents. . (2007). Summary of budget for fiscal year 2007.

Moe, T. M. (1990). The politics of structural choice: Toward a theory of public bureaucracy. In Williamson (Ed.), Organization theory (pp. 116-53). New York: Oxford University Press. 
Musgrave, R. A. (1981). Leviathan cometh-or does he? In H. F. Ladd and T. M. Tideman (Eds.), Tax and expenditure limitations (pp. 77-120). Washington, DC: The Urban Institute.

Niskanen, W. A. (1971). Bureaucracy and representative government. Chicago: Aldine Atherton.

North, D. C. (1990). Institutions, institutional changes and economic performance. Cambridge University Press.

Ophuls, W. (1973). Leviathan or oblivion. In H. E. Daly (Ed.), Toward a steady state economy. San Francisco: Freeman.

Ostrom, E. (1986). An agenda for the study of institutions. Public Choice, 48: 3-25. . (1990). Governing the commons. Cambridge University Press. . (2005). Understanding institutional diversity. Princeton, NJ: Princeton University Press.

Peacock, A. T. (1983). Public x-inefficiency: Informational and institutional constraints. In H. Hanusch (Ed.), Anatomy of government deficiencies. Berlin: Springer.

Perry, J. L., \& L. R. Wise. (1990). The motivational bases of public service. Public Administration Review, 370.

Peters, G. (1978). The politics of bureaucracy: A comparative perspective. New York: Longman.

Presidential Committee on Government Innovation and Decentralization. (2005). Innovations in finance and taxation in participatory government.

Rainey, H. G. (1983). Pubic agencies and private firms: Incentive structure, goals, and individual roles. Administration and Society, 15: 207-42.

Rubin, I. S. (2006). The politics of public budgeting: Getting and spending, borrowing and balancing, 5th ed. Washington, DC: CQ Press.

Ryu, K. J. (2004). A study on the introduction of top-down budgeting. Dissertation, Seoul National University.

Ryu, J. E, C. J. Bowling, C. L. Cho, \& D. S. Wright. (2007). Effects of administrators' aspirations, political principals' priorities, and interest groups' influence on state agency budget requests. Public Budgeting and Finance, 22-49.

Schick, A. (2002). Does budgeting have a future? OECD Journal on Budgeting, 2(2): $7-48$.

Shand, D. (1998). Budgetary reforms in OECD member countries. Journal of Public Budgeting, Accounting, and Financial Management, 10(1): 63-88.

Shepsle, K. A., \& B. R. Weingast. (1984). Legislative politics and budget outcomes. In G. B. Mills and J. L. Palmer (Ed.), Federal budget policy in the 1980s (pp. 34367). Washington, DC: The Urban Institute Press.

Shin, M. S. (2007). Public financial administration. Seoul: Daeyoung Press. 
Sigelman, L. (1986). The bureaucrat as a budget maximizer: An assumption examined. Public Budgeting and Finance, 6(1): 50-59.

Smith, R. J. (1981). Resolving the tragedy of the commons by creating private property rights in wildlife. CATO Journal, 1: 467.

Tullock, G. (1965). The politics of bureaucracy. Washington, DC: The Public Affairs Press.

Von Hargen, J. (2007). Budgeting institutions for better fiscal performance. In A. Shah (Ed.), Budgeting and budgetary institutions: Public sector governance and accountability series (pp. 27-51). Washington, DC: The World Bank.

Von Hargen, J., \& Harden. (1966). Budget process and commitment to fiscal discipline. IMF Working Paper WP96/78.

Welch, W. P. (1983). The political feasibility of full ownership property rights: The case of pollution and fisheries. Policy Sciences, 16:171.

Wildavsky, A. (1988). The new politics of the budgetary process. Glenview, IL: Scott, Foresman and Company.

Wildavsky, A., \& N. Caiden. (2004). The new politics of the budgetary process, 5th ed. New York: Pearson Longman.

Wilson, J. Q. (1989). Bureaucracy: What government agencies do and why they do it. New York: Basic Books.

Yun, S. S. (2003). Budgeting theory. Seoul: Nanam Press.

Yun, Y. J. (2007). New public financial administration. Seoul: Daeyoung Press. 